\title{
Carbon and nitrogen cycling during old-field succession: Constraints on plant and microbial biomass
}

\author{
DONALD R. ZAK ${ }^{1,2, *}$, DAVID F. GRIGAL ${ }^{1}$, SCOTT GLEESON ${ }^{2,3} \&$ \\ DAVID TILMAN ${ }^{2}$ \\ 'Departments of Soil Science and of Ecology and Behavioral Biology, University of Minnesota, St. \\ Paul, Minnesota 55108, USA (" present address: School of Natural Resources, The University of \\ Michigan, Ann Arbor, MI 48109-1115, USA), 'Department of Ecology and Behavioral Biology, \\ University of Minnesota, Minneapolis, Minnesota 55155 ( ${ }^{3}$ present address: School of Biology \\ Sciences, University of Kentucky, Lexington, KY 40506, USA)
}

Accepted 4 May 1990

Key words: Carbon cycling, nitrogen cycling, microbial biomass, plant biomass, secondary succession, soil organic matter

\begin{abstract}
Soil $\mathrm{C}$ and $\mathrm{N}$ dynamics were studied in a sequence of old fields of increasing age to determine how these biogeochemical cycles change during secondary succession. In addition, three different late-successional forests were studied to represent possible "steady state" conditions. Surface soil samples collected from the fields and forests were analyzed for total $\mathrm{C}, \mathrm{H}_{2} \mathrm{O}$-soluble $\mathrm{C}$, total $\mathrm{N}$, potential net $\mathrm{N}$ mineralization, potential net nitrification, and microbial biomass. Aboveand belowground plant biomass was estimated within each of the old field sites.

Temporal changes in soil organic $\mathbf{C}$, total $\mathbf{N}$ and total plant biomass were best described by a gamma function $\left[y=a t^{b} \mathrm{e}^{c t d}+f\right]$ whereas a simple exponential model $\left[y=a\left(1-\mathrm{e}^{-b t}\right)+c\right]$ provided the best fit to changes in $\mathrm{H}_{2} \mathrm{O}$-soluble $\mathrm{C}, \mathrm{C}: \mathrm{N}$ ratio, microbial $\mathrm{C}$, and microbial $\mathrm{N}$. Potential $\mathrm{N}$ mineralization and nitrification linearly increased with field age; however, rates were variable among the fields. Microbial biomass was highly correlated to soil $\mathrm{C}$ and $\mathrm{N}$ pools and well correlated to the standing crop of plant biomass. In turn, plant biomass was highly correlated to pools and rates of $\mathrm{N}$ cycling.

Patterns of $\mathrm{C}$ and $\mathrm{N}$ cycling within the old field sites were different from those in a northern hardwood forest and a xeric oak forest; however, nutrient dynamics within an oak savanna were similar to those found in a 60 -yr old field. Results suggest that patterns in $\mathrm{C}$ and $\mathrm{N}$ cycling within the old-field chronosequence were predictable and highly correlated to the accrual of plant and microbial biomass.
\end{abstract}

\section{Introduction}

Carbon $(\mathrm{C})$ and nitrogen $(\mathrm{N})$ cycles within terrestrial ecosystems are intimately linked through patterns of plant and microbial activity. Plant productivity is often limited by the rate at which microbes liberate ammonium $\left(\mathrm{NH}_{4}^{+}\right)$from soil organic matter; a limitation that has been studied within numerous ecosystems. In turn, microbial growth within the soil is often constrained by the quantity of labile C (Grey \& Williams 1971) supplied through the above- and belowground production of plant litter. The common limitation of $\mathrm{N}$ for plant growth and $\mathrm{C}$ for microbial growth suggests that temporal patterns of plant and microbial activity should be closely related. 
Old-field succession sometimes begins on nutrient poor soils that are low in organic matter (Odum 1960; Gay \& Dwyer 1965; Golley 1965; Monk \& Gabrielson 1985; Inouye et al. 1987; Tilman 1987). For example, $N$ contents of forest and prairie soils are often twice those of recently abandoned agricultural fields in east-central Minnesota (Inouye et al. 1987; Pastor et al. 1987). As a result, the composition and productivity of seral plant communities in this region are often limited by quantities of soil N (Inouye et al. 1987; Tilman 1986, 1987). Although $\mathrm{N}$ availability can restrict plant productivity, total soil $\mathrm{N}$ gradually increases during secondary succession (Inouye et al. 1987) accompanied by a concomitant increase in $\mathbf{N}$ mineralization (Pastor et al. 1987). Within N-limited ecosystems, microbial biomass dynamics should be highly correlated to patterns of plant growth because plant production provides the primary substrate for heterotrophic metabolism.

Several models have been used to describe changes in ecosystem dynamics during secondary succession (Odum 1969; Botkin et al. 1972; Bormann \& Likens 1979; Gorham et al. 1979; Covington 1981; Peet 1981; Pastor \& Post 1986). Most functions predicting changes in ecosystem production and nutrient accrual show a relatively linear increase after disturbance, followed by a saturation or a "dynamic steady-state" condition late in secondary succession. Although numerous studies have investigated temporal patterns of primary production and nutrients, few have focused on the processes regulating microbial biomass within the soil (Insam \& Domsch 1988).

We hypothesized that accrual of plant and microbial biomass are highly correlated during secondary succession because of the reciprocal nature of $\mathrm{C}$ and $\mathrm{N}$ cycles (Pastor \& Post 1986). We reasoned that low rates of plant production and high rates of decomposition should cause soil organic $\mathrm{C}$ and $\mathrm{N}$ to decline early in secondary succession, accrue during mid-sucesssion when production exceeds decomposition, and reach an equilibrium when rates are equivalent late in secondary succession (Covington 1981). Therefore, the "carrying capacity" of the soil for microbial biomass (van Veen et al. 1985) should directly reflect this pattern because heterotrophic growth is contingent on $\mathrm{C}$ inputs from plant production. To test this, we determined pools and fluxes of $\mathrm{C}$ and $\mathrm{N}$, along with plant and microbial biomass, in an old-field chronosequence where plant production is limited by $\mathrm{N}$ availability. In addition, we studied three forests to compare soil $\mathrm{C}$ and $\mathrm{N}$ dynamics of relatively late successional ecosystems with those of the old fields; we considered the forests to represent possible "steady state" conditions.

\section{Methods}

Study site

The Cedar Creek Natural History Area (CCNHA) is located approximately $50 \mathrm{~km}$ north of Minneapolis, Minnesota in east-central Minnesota. The climate 
of the study area is continental with a mean annual temperature of $6{ }^{\circ} \mathrm{C}$ and annual precipitation of $66 \mathrm{~cm}$ (Grigal et al. 1974). The present landscape formed during the last glacial retreat (ca. 12,000 yrs B.P.) and is composed of wellsorted outwash sands, often exceeding $20 \mathrm{~m}$ in depth. The regional water table lies within several meters of the soil surface in the highest elevations and is near or at the surface in low-lying areas. As a consequence, the CCNHA is composed of a mosaic of upland and wetland ecosystems. The dominant ecosystems consist of oak savanna, prairie, upland forest, marsh, and swamp (Cushing 1963).

We studied $\mathrm{C}$ and $\mathrm{N}$ dynamics in a series of fourteen old fields that ranged in age from 1 to 60 years following agricultural abandonment (Table 1). The 1-10 yr old fields form a series of adjacent plots $(0.2 \mathrm{ha})$ that were sequentially abandoned over the past 10 years. The 1-yr-old field was planted to rye in 1985 , maintained in fallow during 1986 by repeated disking during the growing season, and was then abandoned in 1987. In addition to the old field sites, we studied three different late-successional forests that commonly occur in eastcentral Minnesota. The forests we studied included an oak savanna, a forest dominated by upland pin oak (Quercus ellipsoidalis E.J. Hill), and a northern hardwood forest (Table 1). There was no recent evidence of disturbance within the forested sites and all probably regenerated following fire. Ovington et al. (1963) and Reiners (1972) have described the savanna and upland pin oak forest in detail.

In addition to occurring within a single climatic regime, the sites we studied all occurred on the same landform and all had similar patterns of soil development. Soil in the 60-year-old field was an Alfic Udipsamment, whereas the soil of the remaining fields and forests was a Typic Udipsamment (Grigal et al. 1974). The differences in plant community composition and structure primarily result from disturbance history and its influence on resource $(\mathrm{N})$ availability (Inouye et al. 1987). We therefore propose that the old field sites constitute a valid chronosequence; differences among them result from disturbance history and not from differences in climatic or edaphic conditions.

\section{Soil analysis}

In each of the old-field and forest sites, we randomly established a $25-\mathrm{m}$, north-south transect for soil sampling. Sample points were located at $5-\mathrm{m}$ intervals along the transect, and three soil samples were collected at a distance of $1.0 \mathrm{~m}$ and at an azimuth of $0^{\circ}, 120^{\circ}$, and $240^{\circ}$ from each point. Samples consisted of a core $3.8 \mathrm{~cm}$ in diameter and $10 \mathrm{~cm}$ in depth collected from the surface of the mineral soil. The three cores collected at each point were composited in the field, refrigerated, and returned to the laboratory for analysis. One additional soil sample was collected at each sampling point to determine soil bulk density. All soil sampling was conducted on 23 April 1987.

Samples used for biological and chemical analyses were homogenized by repeated mixing within polyethylene bags. Total $\mathrm{N}$, organic- $\mathrm{C}$ and $\mathrm{H}_{2} \mathrm{O}$-soluble 
Table 1. Site characteristics of fourteen old fields and three forests used to determine patterns of carbon and nitrogen dynamics during secondary succession.

\begin{tabular}{|c|c|c|c|}
\hline Site & $\begin{array}{l}\text { Age }^{1} \\
\text { (yr) }\end{array}$ & $\begin{array}{l}\text { Soil }^{2} \\
\text { pH }\end{array}$ & Dominant vegetation \\
\hline I. Old field ${ }^{3}$ & 1 & 4.5 & $\begin{array}{l}\text { Ambrosia artemisiifolia } \\
\text { Setaria lutescens } \\
\text { Mullugo verticillata } \\
\text { Polygonum convolvulus }\end{array}$ \\
\hline $46-3$ & 3 & 5.0 & $\begin{array}{l}\text { Agrostis scabra } \\
\text { Ambrosia artemisiifolia } \\
\text { Crepis tectroum } \\
\text { Digitaris ischaemum } \\
\text { Polygonum convolvulus }\end{array}$ \\
\hline $46-5$ & 5 & 5.3 & $\begin{array}{l}\text { Agropyon repens } \\
\text { Agrostis scabra } \\
\text { Ambrosia artemisiifolia } \\
\text { Crepis tectorum } \\
\text { Digitaris ichaemum } \\
\text { Hedeoma hispida } \\
\text { Polygonum convolvulus }\end{array}$ \\
\hline $46-6$ & 6 & 5.3 & $\begin{array}{l}\text { Agropyon repens } \\
\text { Agrostis scabra } \\
\text { Digitaris ichaemum } \\
\text { Hedeoma hispida } \\
\text { Polygomum convolvulus }\end{array}$ \\
\hline $46-7$ & 7 & 5.3 & $\begin{array}{l}\text { Agrostis scabra } \\
\text { Agropyon repens } \\
\text { Digitaris ichaemum } \\
\text { Hedeoma hispida } \\
\text { Polygonum convolvulus }\end{array}$ \\
\hline $46-8$ & 8 & 5.4 & $\begin{array}{l}\text { Agropyon repens } \\
\text { Agrostis scabra } \\
\text { Ambrosia artemisiifolia } \\
\text { Digitaris ichaemum } \\
\text { Hedeoma hispida } \\
\text { Polygonum convolvulus }\end{array}$ \\
\hline $46-9$ & 9 & 5.3 & $\begin{array}{l}\text { Agropyon repens } \\
\text { Agrostis scabra } \\
\text { Ambrosia artemisiifolia } \\
\text { Digitaris ichaemum } \\
\text { Hedeoma hispida } \\
\text { Polygonum convolvulus }\end{array}$ \\
\hline $46-10$ & 10 & 5.2 & $\begin{array}{l}\text { Agropyron repens } \\
\text { Agrostis scabra } \\
\text { Ambrosia artemisiifolia } \\
\text { Digitaris ichaemum } \\
\text { Hedeoma hispida } \\
\text { Polygonum convolvulus }\end{array}$ \\
\hline
\end{tabular}


Table 1 (continued).

\begin{tabular}{|c|c|c|c|}
\hline Site & $\begin{array}{l}\text { Age }^{1} \\
(y r)\end{array}$ & $\begin{array}{l}\text { Soil }^{2} \\
\mathrm{pH}\end{array}$ & Dominant vegetation \\
\hline 29 & 19 & 5.7 & $\begin{array}{l}\text { Agropyron repens } \\
\text { Berteroa incana }\end{array}$ \\
\hline 22 & 30 & 5.2 & $\begin{array}{l}\text { Schizachyrium } \\
\text { scoparium } \\
\text { Poa pratensis }\end{array}$ \\
\hline 76 & 35 & 5.4 & $\begin{array}{l}\text { Schizachyrium } \\
\text { scoparium } \\
\text { Ceanothus americanis } \\
\text { Solidago numeralis } \\
\text { Solidago speciosa }\end{array}$ \\
\hline 35 & 46 & 5.4 & $\begin{array}{l}\text { Andropogon gerardii } \\
\text { Artemisia ludoviciana } \\
\text { Carex sp. } \\
\text { Cyperus siliculmis }\end{array}$ \\
\hline 69 & 53 & 5.4 & $\begin{array}{l}\text { Schizachyruim } \\
\text { scoparium } \\
\text { Artemisia ludoviciana }\end{array}$ \\
\hline 72 & 60 & 5.4 & $\begin{array}{l}\text { Andropogon gerardii } \\
\text { Artemisia ludoviciana } \\
\text { Poa pratensis } \\
\text { Rubus spp. }\end{array}$ \\
\hline \multicolumn{4}{|l|}{ II. Forest } \\
\hline Oak savanna & - & 5.0 & $\begin{array}{l}\text { Quercus macrocarpa } \\
\text { Artemisia ludoviciana } \\
\text { Carex muhlenbergii } \\
\text { Sorghastrum nutans }\end{array}$ \\
\hline Upland pin oak & - & 52 & $\begin{array}{l}\text { Quercus ellipsoidalis } \\
\text { Corylus americana } \\
\text { Carex muhlenbergii }\end{array}$ \\
\hline Northern hardwood & - & 4.7 & $\begin{array}{l}\text { Quercus rubra } \\
\text { Acer succhurum } \\
\text { Acer rubum } \\
\text { Oryzopsis asperifolia }\end{array}$ \\
\hline
\end{tabular}

\footnotetext{
${ }^{1}$ Field age in 1987
}

${ }^{2}$ Determined by a $1: 1$ soil-deionized water paste.

${ }^{3}$ Soil of the 60-year-old field was an Alfic Udipsamment, whereas the soil of the remaining fields and forests was a Typic Udipsamment.

$\mathrm{C}$ were determined using air-dried soil, whereas field-moist samples were used for analysis of microbial biomass, net $\mathrm{N}$ mineralization, net nitrification and extractable $\mathrm{NH}_{4}^{+}$and $\mathrm{NO}_{3}^{-}$. Total soil $\mathrm{N}$ was determined by digesting air-dried soil in a block digester with concentrated $\mathrm{H}_{2} \mathrm{SO}_{4}$ and $\mathrm{HgO}$ as a catalyst. Ammonium- $\mathbf{N}$ in the digest was determined colorimetrically with a Technicon Autoanalyzer II (Technicon 1977a). Organic carbon was determined by com- 
bustion in a LECO automatic C analyzer (LECO Corp., St. Joseph, Michigan, USA) and $\mathrm{H}_{2} \mathrm{O}$-soluble $\mathrm{C}$ was measured following the procedure of Buford \& Bremner (1975). Soil $\mathrm{pH}$ was measured using a 1:1 soil-deionized water paste. A 10-g subsample of field-moist soil was oven dried at $105^{\circ} \mathrm{C}$ to determine gravimetric moisture content; all nutrient contents are expressed on an oven-dry weight basis.

Microbial biomass $\mathrm{C}$ and $\mathrm{N}$ were estimated using the $\mathrm{CHCl}_{3}$ fumigationincubation procedure (Jenkinson \& Powlson 1976, Voroney \& Paul 1984). A 20 - $\mathrm{g}$ subsample from each core was fumigated for $18 \mathrm{~h}$ with ethanol-free $\mathrm{CHCl}_{3}$, then inoculated with $0.3 \mathrm{~g}$ of fresh soil. A second $20 \mathrm{~g}$ subsample, which served as a control, was kept at room temperature in a moist desiccator during the $18 \mathrm{~h}$ fumigation. After a 10-day incubation in air-tight glass jars, a gas sample was removed for $\mathrm{CO}_{2}$ analysis by gas chromatography. Fumigated and control samples were extracted with $1 \mathrm{M} \mathrm{KCl}$ and analyzed for $\mathrm{NH}_{4}^{+}-\mathrm{N}$ and $\mathrm{NO}_{3}^{-}-\mathrm{N}$ with a Technicon Autoanalyzer II (Technicon 1977b, 1978). Microbial C was determined by dividing the flush of $\mathrm{CO}_{2}-\mathrm{C}$ in fumigated samples by 0.41 (Voroney \& Paul 1984). The quantity of $\mathrm{CO}_{2}-\mathrm{C}$ evolved from unfumigated controls was not subtracted from fumigated samples. Microbial $\mathrm{N}$ was estimated by dividing the flush of $\mathrm{N}$ ( $\mathrm{N}$ in fumigated samples minus $\mathrm{N}$ in control samples) by a correction factor $\left(k_{n}\right)$. Correction factors were calculated for each sample using the equation of Voroney and Paul $\left(1984 ; k_{n}=-0.014\left(\mathrm{C}_{\mathrm{f}}\right)\right.$ $\left.N_{f}\right)+0.39$, where: $C_{f}$ and $N_{f}$ are the flush of $C$ and $N$ from fumigated samples, respectively).

Potential net $\mathrm{N}$ mineralization and net nitrification were estimated by an aerobic laboratory incubation (Vitousek et al. 1982). A 10-g subsample of field most soil was extracted with $2 \mathrm{M} \mathrm{KCl}$ and analyzed for $\mathrm{NH}_{4}^{+}-\mathrm{N}$ and $\mathrm{NO}_{3}^{-}-\mathrm{N}$ using a Technicon Autoanalyzer II (Technicon 1977b, 1978). A second 10-g subsample was incubated at $30^{\circ} \mathrm{C}$ for 8 weeks in the dark. Incubated samples were maintained at field capacity $(0.03 \mathrm{MPa})$ by daily additions of deionized $\mathrm{H}_{2} \mathrm{O}$. Following the 8-week incubation, samples were extracted and analyzed for $\mathrm{NH}_{4}^{+}-\mathrm{N}$ and $\mathrm{NO}_{3}^{-}-\mathrm{N}$ as described above. Potential net $\mathrm{N}$ mineralization was calculated as the difference in inorganic $\mathrm{N}$ concentrations between incubated samples and initial values. Potential nitrification was calculated by subtracting initial $\mathrm{NO}_{3}^{-}$concentrations from those in incubated samples.

\section{Plant biomass}

Plant biomass was measured along a separate transect, $100 \mathrm{~m}$ in length, established within each old field. The transects used for plant sampling were located adjacent (ca. $5 \mathrm{~m}$ ) to those used to collect soil samples. Aboveground plant biomass was sampled by clipping (at the soil surface) the entire contents of five $0.1-\mathrm{m}^{2}$ plots equally spaced along each transact. Belowground plant biomass was estimated by collecting three soil cores $4.8 \mathrm{~cm}$ in diameter and $30 \mathrm{~cm}$ in depth from within each $0.1-\mathrm{m}^{2}$ plot. Plant roots were separated from soil material by hand, and both above- and belowground plant tissues were oven 
dried at $80^{\circ} \mathrm{C}$ to a constant weight. Plant biomass is the sum of above- and belowground tissue per unit area $\left(\mathrm{g} \mathrm{m}^{-2}\right)$. All plant sampling was conducted from 13 to 30 July 1987.

\section{Statistical analyses}

Regression analyses were used to correlate changes in $\mathrm{C}$ and $\mathrm{N}$ dynamics with old field age. Data were fit to a linear function, simple exponential equation $\left[y=a\left(1-\mathrm{e}^{-k t}\right)+c\right]$ and a gamma function $\left[y=a t^{b} \mathrm{e}^{c t^{d}}+f\right] ; t$ in each equation represents time in years. The regression analyses were performed using the Marquardt procedure (Bard 1974) and best fit was determined as the model which produced the smallest residual mean square. Linear regression analysis was used to correlate plant and microbial biomass with soil nutrient contents (Snedecor \& Cochran 1967). Both linear and nonlinear regression analyses were performed using the Statistical Analysis System (SAS) for personal computers (SAS Institute 1987). Significance of the regression analyses was accepted at alpha $=0.01$. Soil moisture, $\mathrm{pH}$, and nutrient data from the fields and forests were analyzed using principal components analysis (SAS Institute 1987).

\section{Results}

The accumulation of soil organic $\mathrm{C}$ and total $\mathrm{N}$ in the old field chronosequence was best described by the gamma function (Figures $1 \mathrm{a}$ and $1 \mathrm{~b}$ ). One year following agricultural abandonment, soil organic $\mathrm{C}$ and total $\mathrm{N}$ were 1170 and $80 \mathrm{~g} \mathrm{~cm}^{-2}$, respectively. These values declined during the first 6 years of succession and then increased to $2120 \mathrm{~g} \mathrm{~m}^{-2}$ of organic $\mathrm{C}$ and $110 \mathrm{~g} \mathrm{~m}^{-2}$ of total $\mathrm{N}$ in the 60 -yr-old field. Organic $\mathrm{C}$ in the late successional forests ranged from $2880 \mathrm{~g} \mathrm{C} \mathrm{m}^{-2}$ in the oak savanna to $4590 \mathrm{~g} \mathrm{C} \mathrm{m}^{-2}$ in the northern hardwood stand (Table 2). Total $\mathrm{N}$ was $132 \mathrm{~g} \mathrm{~N} \mathrm{~m}^{-2}$ and $189 \mathrm{~g} \mathrm{~N} \mathrm{~m}^{-2}$ in the oak savanna and northern hardwood forest, respectively. The upland pin oak forest was intermediate in both cases.

The simple exponential model explained the largest proportion of variability in soil $\mathrm{C}: \mathrm{N}\left(R^{2}=0.603\right)$ and $\mathrm{H}_{2} \mathrm{O}$-soluble $\mathrm{C}\left(R^{2}=0.912\right)$ in the old field chronosequence (Figs. 1c, 1d). Soil C: $\mathrm{N}$ was relatively low (15) in the 1-yr-old field and increased to approximately 18 in fields 10 to 60 years old. Carbon to $\mathrm{N}$ ratios in the forests were much higher and ranged from 21 in the upland pin oak forest to 24 in the northern hardwood stand. Water-soluble $C$ was $3.3 \mathrm{~g} \mathrm{~m}^{-2}$ in the 1-yr-old field and increased to $5.9 \mathrm{~g} \mathrm{C} \mathrm{m}^{-2}$ in the 19-yr-old field. Pools were relatively constant (ca. $6.0 \mathrm{~g} \mathrm{C} \mathrm{m}^{-2}$ ) for fields ranging in age from 30 to 60 years. Water-soluble $\mathrm{C}$ was $6.3 \mathrm{~g} \mathrm{C} \mathrm{m}^{-2}$ in the oak savanna and was similar to the values measured in the older fields. In contrast, pools in the upland pin oak $\left(9.5 \mathrm{~g} \mathrm{C} \mathrm{m}^{-2}\right)$ and northern hardwood forests $\left(10.7 \mathrm{~g} \mathrm{C} \mathrm{m}^{-2}\right)$ were much greater (Table 2).

The simple exponential model also explained a large proportion of the vari- 

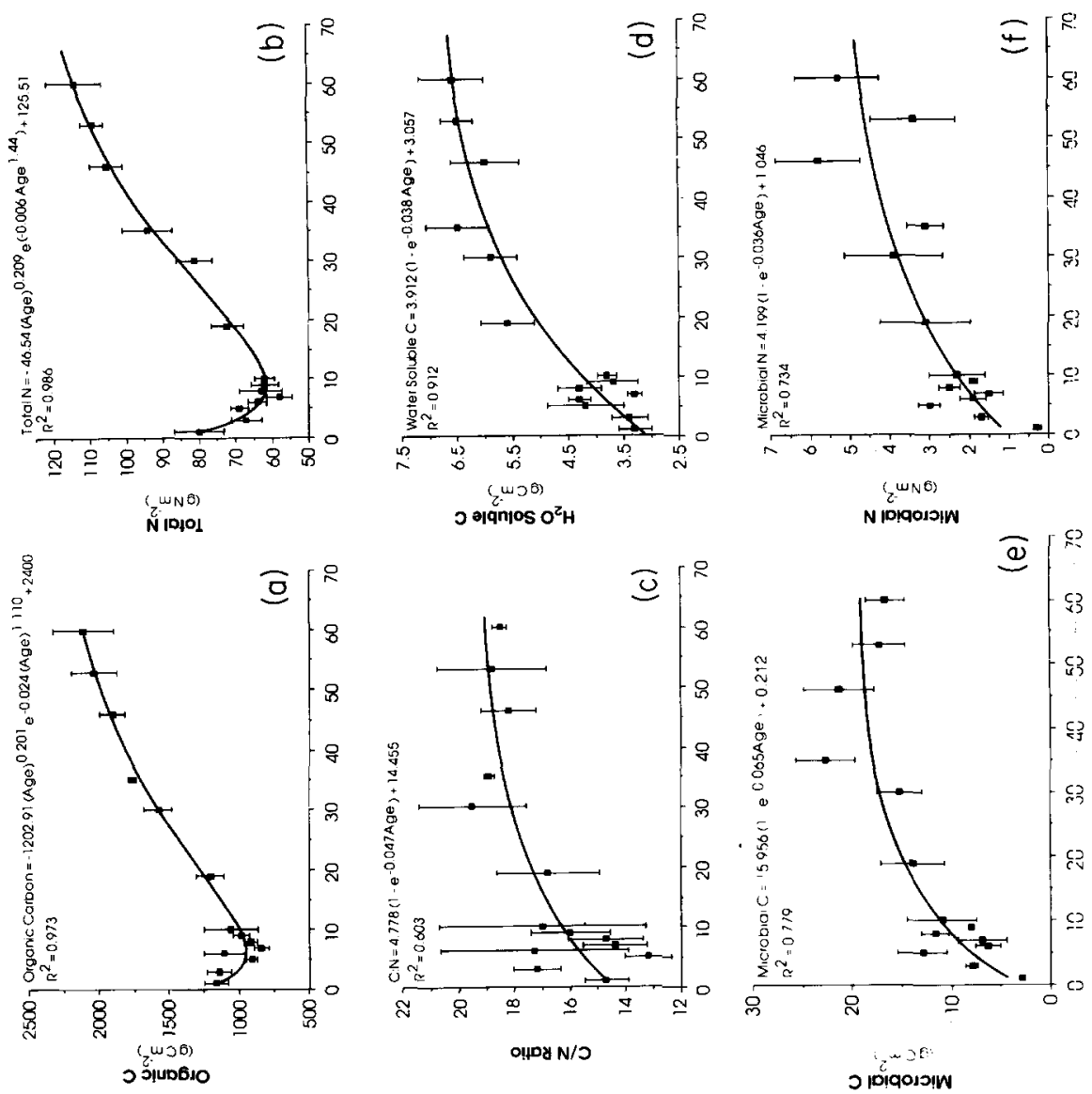

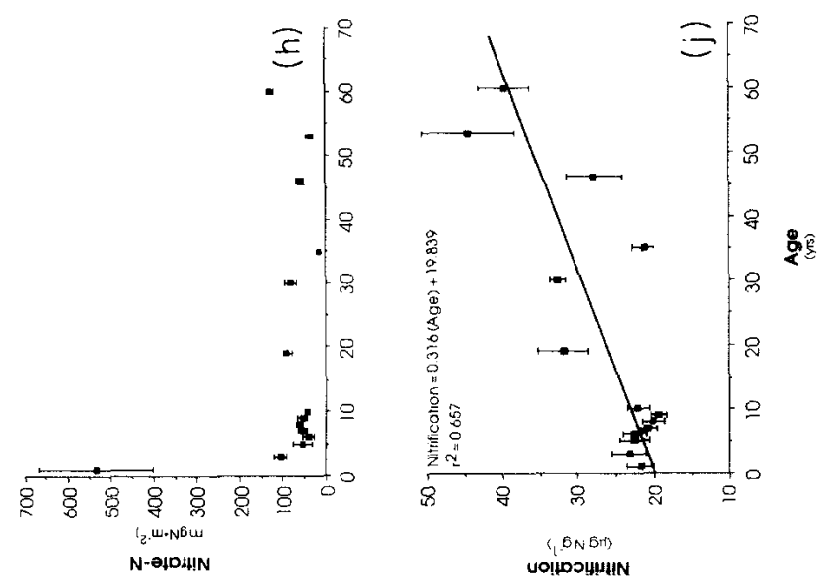

\section{}

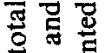

宫密

U.

苋

需哭

○方要

릉

运

氖

음 홈

ज到

웜

要

of

范

항

可焗

8․ㅡㄴ현

9 总

도웛

눙

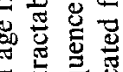

$\Xi$ 苛.

品品

可司

影需

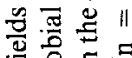

은 $\Xi$

肎焉

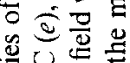

到

$\rightarrow$ 응

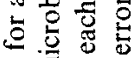

흔 운

है

는 馬

范芯

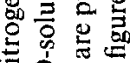

엄웜

ปี

อิ

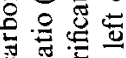

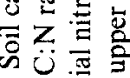

的志

这要咅 
Table 2. Carbon and nitrogen dynamics of three relatively late-successional forest ecosystems common to the Cedar Creek Natural History Area in east-central Minnesota. Values listed are the mcan of five composite soil samples collected in April 1987 within each forest; standard errors are in parentheses.

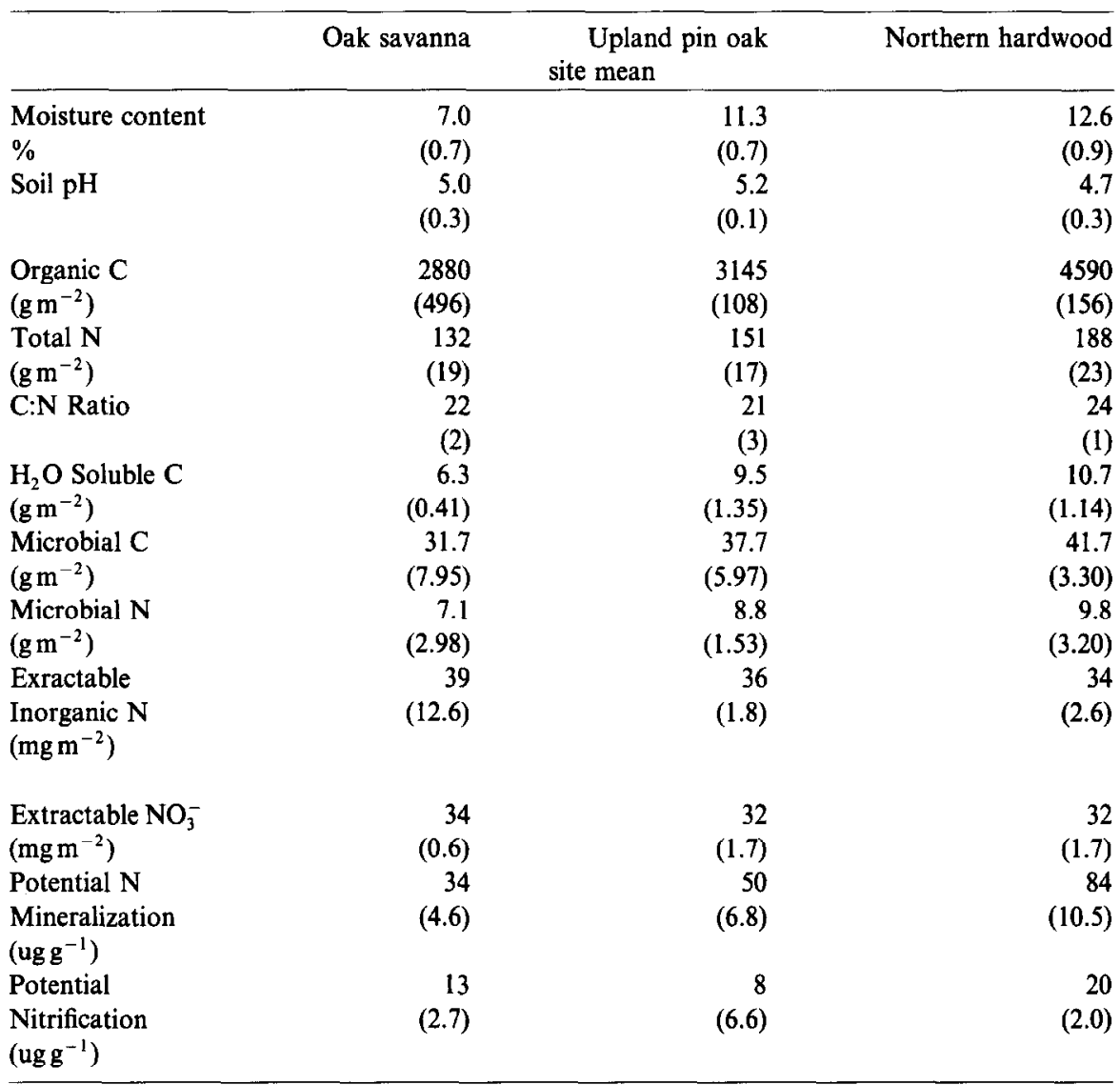

ability in microbial biomass $\mathrm{C}\left(R^{2}=0.779\right)$ and $\mathrm{N}\left(R^{2}=0.734\right)$ among the old field sites (Figs. 1e, 1f). The smallest pools of microbial $\mathrm{C}\left(2.9 \mathrm{~g} \mathrm{C} \mathrm{m}^{-2}\right)$ and $\mathrm{N}$ $\left(0.3 \mathrm{~g} \mathrm{~N} \mathrm{~m}^{-2}\right)$ were measured in the 1-yr-old field. Microbial pools increased up to approximately 30 years following abandonment, after which they remained relatively constant. The $\mathrm{C}: \mathrm{N}$ ratio of microbial biomass ranged from $9.8(1 \mathrm{yr}$ old field) to 3.7 ( $60 \mathrm{yr}$ old field), and microbial $\mathrm{C}$ consistently composed less than $1 \%$ of total organic $\mathrm{C}$. Microbial $\mathrm{C}$ in the forested sites was much greater than pools in the old fields, and ranged from $31.7 \mathrm{~g} \mathrm{Cm}^{-2}$ in the oak savanna to $41.7 \mathrm{~g} \mathrm{~m}^{-2}$ in the northern hardwood forest. Microbial $\mathrm{N}$ displayed an identical pattern (compare Fig. If and Table 2). However, there was a poor agreement between maximum microbial $\mathrm{C}\left(19.0 \mathrm{~g} \mathrm{Cm}^{-2}\right)$ and $\mathrm{N}\left(5.2 \mathrm{~g} \mathrm{~N} \mathrm{~m}^{-2}\right)$ contents predicted from the saturating exponential model and those measured within the forested ecosystems (compare figures le and 1f with Table 2). In general, microbial $\mathrm{C}$ and $\mathrm{N}$ were 1.5 to 2.0 times greater in the forested sites compared 

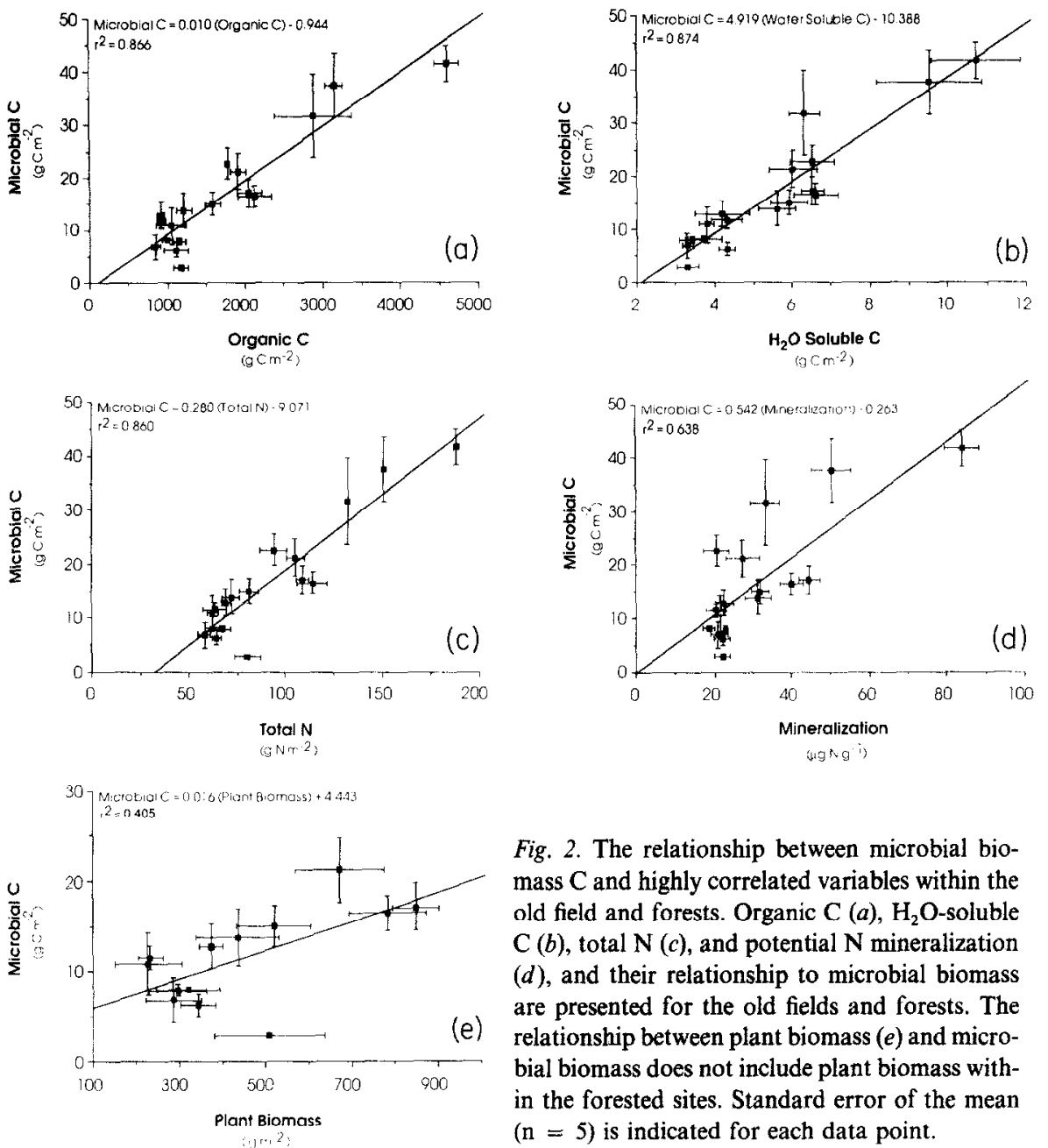

Fig. 2. The relationship between microbial biomass $\mathrm{C}$ and highly correlated variables within the old field and forests. Organic $\mathrm{C}(a), \mathrm{H}_{2} \mathrm{O}$-soluble $\mathrm{C}(b)$, total $\mathbf{N}(c)$, and potential $\mathbf{N}$ mineralization (d), and their relationship to microbial biomass are presented for the old fields and forests. The relationship between plant biomass $(e)$ and microbial biomass does not include plant biomass within the forested sites. Standard error of the mean $(n=5)$ is indicated for each data point.

to the predicted maximum value. In the old field and forest sites, microbial biomass $\mathrm{C}$ was highly correlated to organic $\mathrm{C}\left(r^{2}=0.866\right), \mathrm{H}_{2} \mathrm{O}$-soluble $\mathrm{C}$ $\left(r^{2}=0.874\right)$, total $\mathrm{N}\left(r^{2}=0.850\right)$, potential $\mathrm{N}$ mineralization $\left(r^{2}=0.638\right)$, and plant biomass $\left(r^{2}=0.405\right)$; Fig. 2$)$.

The pools of extractable inorganic $\mathrm{N}$ and $\mathrm{NO}_{3}^{-}$were not significantly correlated with field age (Figs. 1g, $1 \mathrm{~h}$ ), although both displayed a similar pattern. Contents were high 1 yr following agricultural abandonment, declined in the fields 3 to 10 yrs old, and then became quite variable; variability in extractable $\mathrm{NO}_{3}^{-}$was somewhat less. Extractable inorganic $\mathrm{N}$ in the old fields was an order of magnitude greater than pools measured in the forested sites, whereas extractable $\mathrm{NO}_{3}^{-}$contents were equivalent (compare Figs. $1 \mathrm{~g}$, $1 \mathrm{~h}$ with Table 2 ).

Patterns of potential $\mathrm{N}$ mineralization and nitrification in the old field chronosequence were best described by a linear model (Figs. 1i, lj). The slope 
of the regression equation indicated that potential $\mathrm{N}$ mineralization increased at a rate of $0.31 \mathrm{ug} \mathrm{N} \mathrm{g}^{-1} \mathrm{yr}^{-1}$ for the first 60 years of succession; nitrification increased at a similar $\left(0.32 \mathrm{ug} \mathrm{N} \mathrm{g}^{-1} \mathrm{yr}^{-1}\right)$. Mineralization rates in the oak savanna ( $33.8 \mathrm{ug} \mathrm{N} \mathrm{g}^{-1}$ ) were similar to those measured in the older fields, but rates in the upland pin oak $\left(50.4 \mathrm{ug} \mathrm{N}^{-1}\right)$ and northern hardwood forest $\left(84.0 \mathrm{ug} \mathrm{N} \mathrm{g}^{-1}\right)$ were much greater (Table 2). Nitrification consumed $100 \%$ of mineral $\mathrm{N}$ production in the old fields, but a smaller proportion in the forest. Nitrification in the forested sites was greatest in the northern hardwood stand where $24 \%\left(20.3 \mathrm{ug} \mathrm{N} \mathrm{g}{ }^{-1}\right)$ of inorganic $\mathrm{N}$ was oxidized to $\mathrm{NO}_{3}^{-}$. Nitrification was 13.5 and $8.6 \mathrm{ug} \mathrm{Ng}^{-1}$ in the oak savanna and upland pin oak forest, respectively (Table 2 ).

Changes in total plant biomass within the old field chronosequence were best described by the gamma function $\left(R^{2}=0.940\right.$; Fig. 3a). Values for the 35-yearold field were eliminated from the analysis (i.e., an outlier) because the standardized residual was greater than 2 standard deviations. Total plant biomass was $509 \mathrm{~g} \mathrm{~m}^{-2}$ in the 1 -yr-old field, this value decreased to $296 \mathrm{~g} \mathrm{~m}^{-2}$ in the 3 -yr-old field, and then increased to $783 \mathrm{~g} \mathrm{~m}^{-2} 60$ years following agricultural abandonment. Plant biomass within the old field sites was significantly correlated to total soil $\mathrm{N}\left(r^{2}=0.941\right)$, potential $\mathrm{N}$ mineralization $\left(r^{2}=0.783\right)$, potential nitrification $\left(r^{2}=0.766\right)$, soil moisture content $\left(r^{2}=0.497\right)$, and microbial $\mathrm{N}$ $\left(r^{2}=0.411\right.$; Fig. 3$)$.

Principal components analysis of soil moisture, $\mathrm{pH}$, and $\mathrm{C}$ and $\mathrm{N}$ contents clearly separated the fields and forests along a continuum (Fig. 4). Principal components axes 1 and 2 accounted for $81 \%$ of the variation among the sites. Organic C (0.982), microbial C (0.970), total $\mathrm{N}(0.969), \mathrm{H}_{2} \mathrm{O}$-soluble $\mathrm{C}(0.956)$, gravimetric moisture content (0.932); C:N (0.907), microbial $\mathrm{N}(0.907)$ and potential $\mathrm{N}$ mineralization $(0.900)$ received high positive weights on PCA 1. Extractable inorganic $\mathrm{N}(-0.573)$ and extractable $\mathrm{NO}_{3}^{-}(-0.472)$ were negatively weighted. Soil $\mathrm{pH}$ received a large negative weight $(-0.858)$ on PCA 2 , whereas extractable inorganic $\mathrm{N}$ and $\mathrm{NO}_{3}^{-}$shared high positive weights $(0.678$ and 0.798 , respectively). In general, field age increased along PCA 1 with the younger fields occupying the more negative portion of the axis (Fig. 4).

\section{Discussion}

Soil $\mathrm{C}$ and $\mathrm{N}$ dynamics are regulated by a complex set of interactions that change during secondary succession. Soil organic matter pools and $\mathrm{C}$ and $\mathrm{N}$ availability are ultimately controlled by the formation of organic matter through primary production and its loss through the activities of decomposing organisms. Bormann \& Likens (1979) concluded that net primary production was the most important factor influencing ecosystem development in disturbed northern hardwood forests. In the successional sequence that we studied, plant production and the processes by which it is regulated seem to be the most important factors regulating soil organic matter and microbial biomass. 

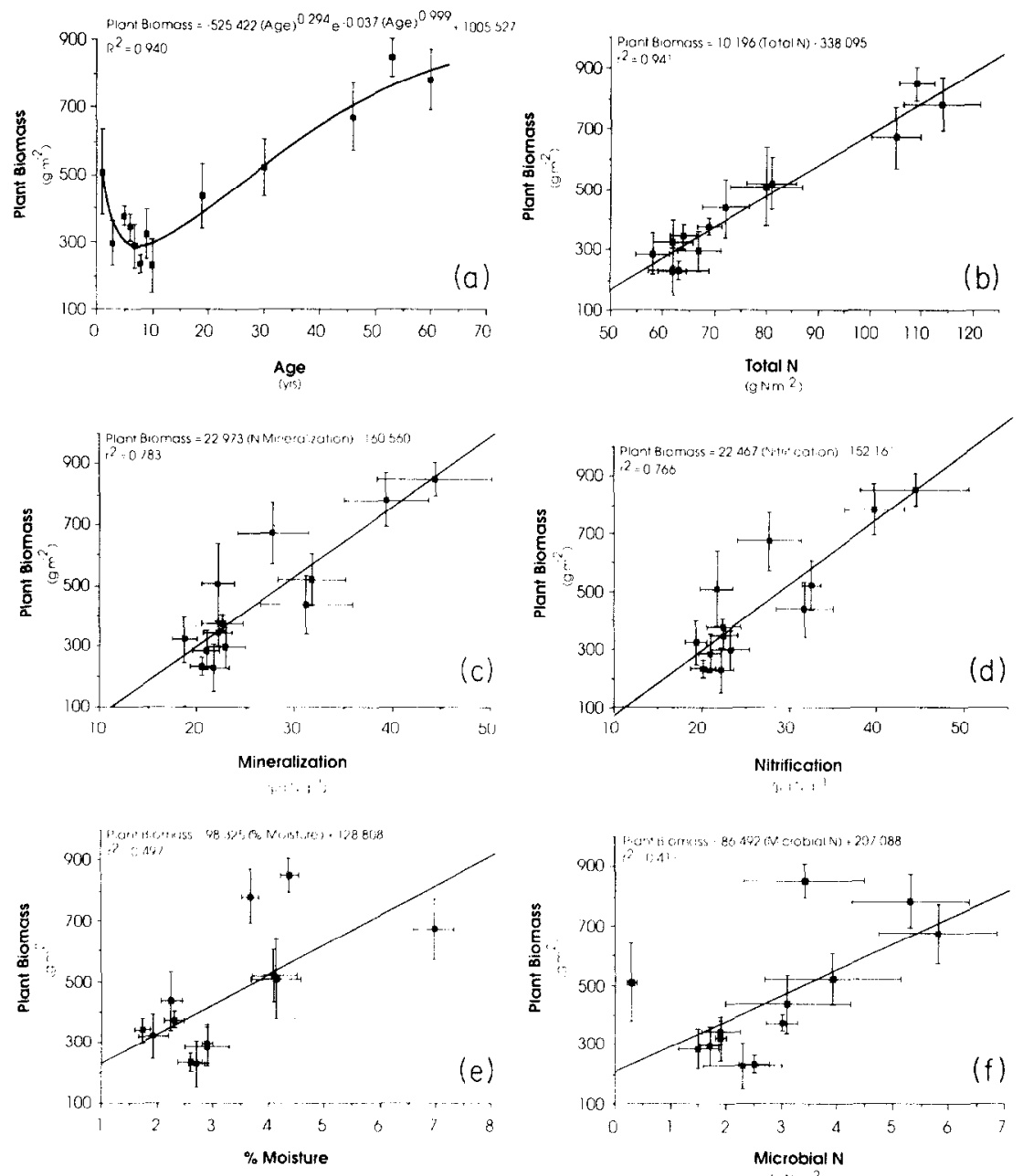

Fig. 3. The relationship between total plant biomass within the old field sites and selected variables. Field age $(a)$, soil total $\mathrm{N}(b)$, potential $\mathrm{N}$ mineralization $(c)$, potential nitrification $(d)$, soil gravimetric moisture $(e)$, and microbial $\mathrm{N}(f)$, were highly correlated to total plant biomass. Standard error of the mean $(n=5)$ is indicated for each data point.

In east-central Minnesota, plant productivity is intimately linked to $\mathrm{N}$ availability (Tilman 1984, 1986, 1987). Experimental $\mathrm{N}$ additions within old-field ecosystems have resulted in shifts in species composition and increases in plant production (Tilman 1986, 1987). Because plant growth at CCNHA is constrained by $\mathrm{N}$ availability, soil organic matter accrual should be controlled by rates of $\mathbf{N}$ input via the atmosphere and through biological $\mathbf{N}$ fixation. Soil total $\mathrm{N}$ increases at a linear rate of $896 \mathrm{mg} \mathrm{N} \mathrm{m}^{-2} \mathrm{yr}^{-1}$ within the old-field soils of CCNHA (calculated from Inouye et al. 1987). Annual atmospheric additions (900 $\mathrm{mg} \mathrm{N} \mathrm{m}^{-2} \mathrm{yr}^{-1}$, Minnesota Pollution Control Agency) account for most of the $\mathbf{N}$ entering the old field ecosystems, whereas biological inputs through 


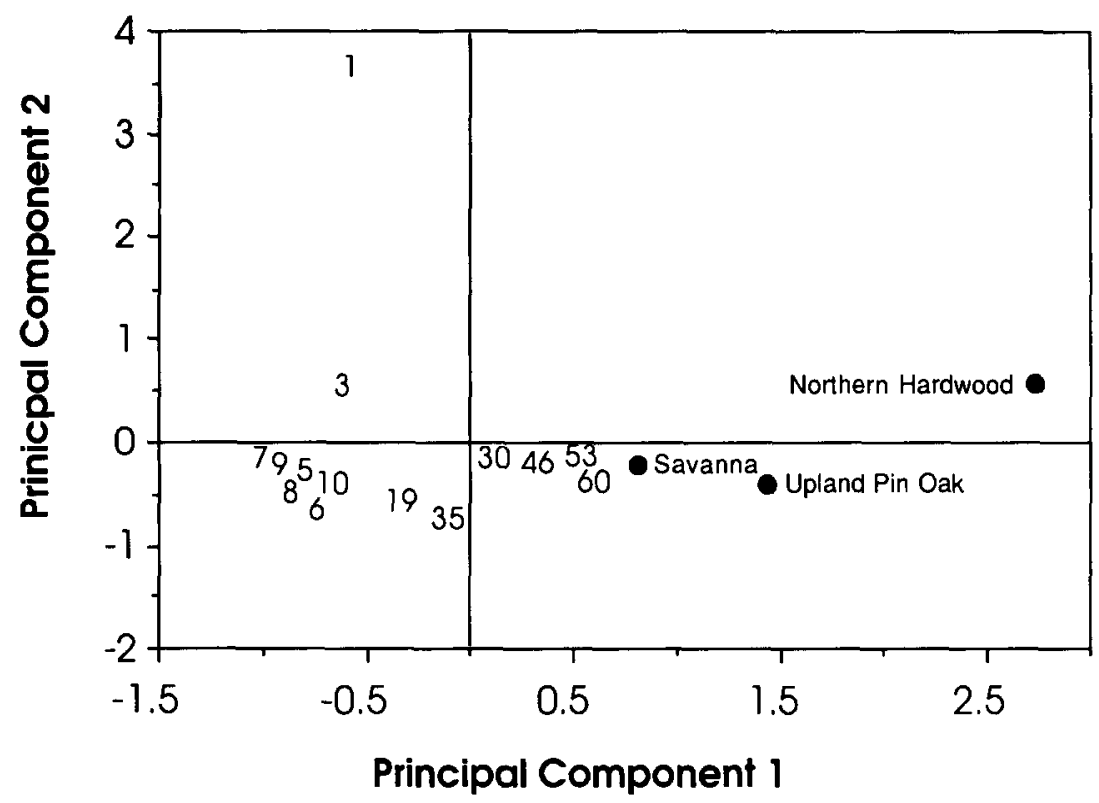

Fig. 4. Principal components analysis of soil $\mathrm{C}$ and $\mathrm{N}$ dynamics within the fourteen old fields and three forests in east Central Minnesota. Numbers within the figure represent field age in 1987 and the forests are labeled by name. The PCA analysis included soil C and $\mathrm{N}$ pools as well as soil pH and gravimetric moisture content.

symbiotic and free-living fixation are minimal (McKone \& Biesboer 1986; Zak \& Johnson, unpublished data). In these $\mathrm{N}$-limited systems, even small $\mathrm{N}$ additions should influence both short- and long-term patterns of plant production.

The patterns of soil organic $\mathrm{C}$ and total $\mathrm{N}$ accrual that we observed suggest that the balance between organic matter production and decomposition changes in a predictable manner during old field succession. Both organic $\mathrm{C}$ and total $\mathrm{N}$ exhibited a decline directly following agricultural abandonment, indicating that rates of decomposition exceeded rates of net production. Covington (1981) found a similar pattern for forest floor organic matter in an age sequence of northern hardwood stands. Although we did not measure rates of organic matter decomposition, total plant biomass declined early in the chrono sequence, suggesting that litter inputs to the soil followed a similar pattern. It is important to note that annuals dominate the plant community during this period (Inouye et al. 1987) and a large proportion of their production undoubtedly enters the litter pool each year. Following the decline early in the chronosequence, soil organic $\mathrm{C}$ and $\mathrm{N}$ began to accrue, suggesting that annual primary production surpassed rates of organic matter decomposition. Production appears to exceed decomposition even 60 years following agricultural abandonment.

The ecological implications of the equation $\left[y=a\left(1-\mathrm{e}^{-k t}\right)+b\right]$ we used 
to describe microbial biomass are important, and suggest that some resource limits microbial proliferation late in the old field succession. Insam and Domsch (1988) observed a similar pattern within a chronosequence of agricultural fields that were reclaimed following surface-mining. However, they found no significant pattern of accumulation in a series of forest plantations (Fagus sylvatica). In both the forest and agricultural chronosequences, microbial biomass was significantly correlated to soil organic C content (Insam \& Domsch 1988), and others have demonstrated a similar relationship across a wide array of soil types (Anderson \& Domsch 1986; Insam et al. 1989).

Heterotrophic growth within the soil is largely controlled by physical factors, such as soil moisture, temperature and texture (Van Veen et al. 1985), and by substrate (C) availability (Clark \& Paul 1970; Grey \& Williams 1971). Because the sites we studied occurred within the same climatic regime and on similar parent material, the pattern of microbial biomass accrual should have arisen from local differences in substrate availability. Burford and Bremner (1975) found a significant relationship between $\mathrm{C}$ mineralization and $\mathrm{H}_{2} \mathrm{O}$-soluble $\mathrm{C}$ concentrations in aerobic soil incubations, and others have suggested that $\mathrm{H}_{2} \mathrm{O}$-soluble $\mathrm{C}$ is an energy source readily metabolized by soil microorganisms (McGill et al. 1981, McGill et al. 1986). In our study, microbial biomass $\mathrm{C}$ was highly correlated to $\mathrm{H}_{2} \mathrm{O}$-soluble $\mathrm{C}$ and soil organic $\mathrm{C}$. The linear relationship between soil $\mathrm{C}$ pools and microbial biomass in the old field and forested sites indicates a constant ratio of microbial biomass to substrate (microbial $\mathrm{C}$ : organic $\mathrm{C}=1: 100$; microbial $\mathrm{C}: \mathrm{H}_{2} \mathrm{O}$-soluble $\mathrm{C}=5: 1$ ). If $\mathrm{H}_{2} \mathrm{O}$-soluble $\mathrm{C}$ is readily metabolized by an active microbial population, then pool turnover should be rapid because it was consistently $20 \%$ of microbial C.

The $\mathrm{C}$ and $\mathrm{N}$ contents of soil organic matter are highly correlated, and it could be argued that we cannot determine whether $\mathrm{C}$ or $\mathrm{N}$ was the limiting resource for soil microorganisms. Anderson and Domsch (1986) also found that microbial biomass was highly correlated to both soil organic $\mathrm{C}$ and total $\mathrm{N}$. If $\mathrm{N}$ availability limited microbial populations, then the old field soils should be characterized by rapid rates of net immobilization. However, net $\mathrm{N}$ mineralization commonly occurs in both laboratory and field soil incubations (Pastor et al. 1987), which provides support for our conclusion that microbial biomass is limited by (labile) $\mathrm{C}$ availability.

Soil microbes are generally thought to represent an important sink and source of plant nutrients (Paul \& Juma 1981; Vitousek \& Matson 1984, 1985; Zak et al. 1990), and are the main regulators of C dynamics within the soil (McGill et al. 1986). In the $\mathrm{N}$-limited ecosystems we studied, microbial biomass was well correlated with laboratory $\mathrm{N}$ mineralization potentials. However, significant insights regarding microbial activity cannot be directly gained from a static measurement of microbial biomass. Various studies have suggested that most soil microbes are inactive due to energy limitations within the soil system (Grey \& Williams 1971; McGill et al. 1986). In addition, the $\mathrm{CHCl}_{3}$ fumigationincubation procedure only provides an estimate of microbial biomass. Actual contents appear to be a function of species composition and the physiological 
ability of the microbial community to respond following fumigation (Ingham and Horton 1987). Nonetheless, in early spring, microbial biomass (measured by the $\mathrm{CHCl}_{3}$ fumigation-incubation procedure) was well correlated to plant biomass, and seems to be a particularly good indicator of $\mathrm{N}$ availability at CCNHA.

The linear increase in potential $\mathrm{N}$ mineralization and nitrification was much different from the general patterns of $\mathrm{C}$ and $\mathrm{N}$ accrual within the old field chronosequence. Pastor et al. (1987) obtained a similar pattern for annual $\mathrm{N}$ mineralization rates within a subset of the sites we studied. Although rates generally increased with field age, the relative proportion of total soil $\mathrm{N}$ mineralizer decreased with field age (Pastor et al. 1987). Their results suggest that organic matter quality declines during secondary succession, and similar observations have been made in grassland ecosystems (Schimel et al. 1985). Our results differ in that both relative $\mathrm{N}$ mineralization rates $(\%$ of total $\mathrm{N}$ mineralized $=4.4 \% \pm 0.73 \%$ ) and the ratio of $\mathrm{H}_{2} \mathrm{O}$-soluble $\mathrm{C}$ to organic $\mathrm{C}$ $(0.37 \% \pm 0.05 \%)$ remained relatively constant over the chronosequence. Moreover, soil $\mathrm{C}: \mathrm{N}$ ratios differed little (i.e., ranged from 14 to 19 ) among the old field sites. Although species composition changes dramatically in the old-field chronosequence, it seems to have little influence on organic matter chemistry.

The series of old fields and forests we studied has been referred to as the prairie-savanna-oak woodland sequence by Ovington et al. (1963). They found both net primary production and total biomass increased among these sites and suggested that they represented different stages of secondary succession. The principal components analysis of soil $\mathrm{C}$ and $\mathrm{N}$ data indicate a distinct temporal pattern in the ordination. The ordering of sites by age along PCA 1 indicated that rates and patterns of nutrient cycling were represented by a continuum of temporal change. However, the 1 and 3-year-old fields occupied unique positions in the ordination space resulting from their high $\mathrm{NO}_{3}^{-}$content. Due to recent disturbance, they are undoubtedly more similar to agricultural fields than to native grassland ecosystems. It is interesting to note that the 60-year-old field and oak savanna occupied a similar ordination space suggesting that $\mathrm{C}$ and $\mathrm{N}$ dynamics within these sites are comparable.

Our results suggest that $\mathrm{C}$ and $\mathrm{N}$ dynamics display predictable patterns during secondary succession that can be explained by relatively simple analytical models. In addition, the patterns we found suggest that plant and microbial biomass accrual are intimately linked within the old fields. Heterotrophic growth within the soil seems to be limited by labile organic matter inputs from primary production. In turn, organic matter production is limited by the quantities of $\mathrm{N}$ liberated from soil organic matter and those entering via atmospheric vectors. Because denitrification and leaching losses of $\mathbf{N}$ are small (Grigal \& Zak, unpublished data), atmospheric $\mathbf{N}$ addition must represent a significant proportion of available $\mathrm{N}$ early in secondary succession. More importantly, these inputs may be responsible for the increases in plant production and organic matter accrual. In east-central Minnesota, primary production seems to be the most important process influencing soil organic matter accrual and microbial biomass dynamics during secondary succession. 


\section{Acknowledgements}

This research was supported by a National Science Foundation Grant (BSR 881184) for Long-Term Ecological Research at the Cedar Creek Natural History Area, and by the Minnesota Agricultural Experiment Station under project 25-054. Published as paper No. 17874 of the scientific journal series in that station. We gratefully acknowledge Bob McKane, Barb Delaney, Nancy Johnson, and Dave Wedin for their assistance in the field and laboratory. Deborah Goldberg, George Host, Neil MacDonald, and William Schlesinger provided valuable insights and comments on an earlier draft of this manuscript; we thank them all.

\section{References}

Anderson TH \& Domsch KH (1986) Carbon link between microbial biomass and soil organic matter. In: Proceedings of the Fourth International Symposium on Microbial Ecology. (pp 476-471). Megusar F \& Gantar M (Eds). Slovene Society for Microbiology, Ljubljana, Yugoslavia

Bard Y (1974) Nonlinear Parameter Estimation. Academic Press, New York

Bormann FH \& Likens GE (1979) Pattern and Process in a Forested Ecosystem. Springer-Verlag, NY, 253 pp

Botkin DB, Janak JK \& Wallis JR (1972) Some ecological consequences of a computer model of forest growth. Journal of Ecology 60: 849-872

Burford JR \& Bremner JM (1975) Relationships between the denitrification capacities of soil and total, water-soluble and readily decomposable soil organic matter. Soil Biology and Biochemistry 7: 389-394

Clark FE \& Paul EA (1970) The microflora of grasslands. Advances in Agronomy 22: 375-435

Covington WW (1981) Changes in forest floor organic matter and nutrient content following clear cutting in northern hardwoods. Ecology 62: 41-48

Cushing EJ (1963) Late-Wisconsin pollen stratigraphy in east-central Minnesota. PhD thesis, University of Minnesota, Minneapolis, MN. $165 \mathrm{pp}$

Gay CW \& Dwyer DD (1965) Effects of one year's nitrogen fertilization on native vegetation under clipping and burning. Journal of Range Management 18: 273-277

Golley FB (1965) Structure and function of an old field broomsedge community. Ecological Monographs 35: 113-137

Gorham E, Vitousek PM \& Reiners WA (1979) The regulation of chemical budgets over the course of terrestrial ecosystem succession. Annual Review of Ecology and Systematics 10: 53-84

Grey TRG \& Williams ST (1971) Microbial productivity in the soil. Symposia of the Society for General Microbiology 21: 255-286

Grigal DF, Chamberlain LM, Finney HR, Wroblewski DV \& Gross ER (1974) Soils of the Cedar Creek Natural History Area. Miscellaneous Report 123, University of Minnesota Agricultural Experiment Station, St. Paul, MN, USA

Ingham ER \& Horton KA (1987) Bacterial, fungal and protozoan responses to chloroform fumigation in stored soil. Soil Biology and Biochemistry 19: 545-550

Inouye RS, Huntley NJ, Tilman D, Tester J, Stillwell M \& Zinnel K (1987) Old-field succession on a Minnesota sand plain. Ecology 68: 12-26

Insam H \& Domsch KH (1988) Relationship between soil organic carbon and microbial biomass on chronosequences of reclamation sites. Microbial Ecology 15: 177-188

Insam H, Parkinson D \& Domsch KH (1989) Influence of microclimate on soil microbial biomass. Soil Biology and Biochemistry 21: 211-221 
Jenkinson DS \& Powlson DS (1976) The effects of biocidal treatments on metabolism in soil V. A method for measuring soil biomass. Soil Biology and Biochemistry 8: 208-213

McGill WB, Hunt HW, Woodmansee RG \& Reuss JO (1981) PHOENIX, a model of the dynamics of carbon and nitrogen in grassland soils. In: Clark FE \& Rosswall T (Eds) Terrestrial Nitrogen Cycles (pp 621-626). Ecological Bulletins 33, Stockholm.

McGill WB, Cannon KR, Robertson JA \& Cook FD (1986) Dynamics of soil microbial biomass and water soluble organic $C$ in Breton $L$ after 50 years of cropping two rotations. Canadian Journal of Soil Science 66: 1-19

McKone MJ \& Biesboer DD (1986) Nitrogen fixation in association with the root systems of goldenrods (Solidago L.). Soil Biology and Biochemistry 18: 543-545

Monk CD \& Gabrielson Jr FC (1985) Effects of shade, litter and root competition on old field vegetation in North Carolina. Bulletin of the Torrey Botanical Club 93: 402-406

Odum EP (1960) Organic production and turnover in old field succession. Ecology 41: 34-49.

- (1969) The strategy of ecosystem development. Science 164: 262-270

Ovington JD, Heitkamp D \& Lawrence DB (1963) Plant biomass and productivity of prairie, savanna, oakwood, and maize field ecosystems in central Minnesota. Ecology 44: 52-63

Pastor J \& Post WM (1986) Influence of climate, soil moisture, and succession on forest carbon and nitrogen cycles. Biogeochemistry 2: 2-27

Pastor J, Stillwell MA \& Tilman D (1987) Nitrogen mineralization and nitrification in four Minnesota old fields. Oecologia 71: 481-485

Paul EA \& Juma NG (1981) Mineralization and immobilization of soil nitrogen by microorganisms. In: Clark FE \& Rosswall T (Eds) Terrestrial Nitrogen Cycles (pp 179-195). Ecological Bulletins 33, Stockholm

Peet RK (1981) Changes in biomass and production during secondary forest succession. In: West DC, Shugart HH \& Botkin DB (Eds) Forest Succession: Concepts and Applications (pp 324337). Springer-Verlag, NY

Reiners WA (1971) Structure and energetics of three Minnesota forests. Ecological Monographs 42: 71-94

SAS Institute (1987) SAS/STAT Guide for Personal Computers, 6th edition, SAS Institute, Cary $\mathrm{NC}, 1028 \mathrm{pp}$

Schimel D, Stillwell MA \& Woodmansee RG (1985) Biogeochemistry of C, N, and P in a soil catena of the shortgrass steppe. Ecology 66: 276-282

Snedecor GW \& Cochran WG (1967) Statistical Methods. The Iowa State University Press, Ames IA

Technicon Instruments (1977a) Individual/simultaneous determination of nitrogen and/or phosphorus in BD acid digests. Technicon Industrial Systems, Terrytown, NY. Industrial Method Number 158-71W

- (1977b) Nitrate and nitrite in water and seawater. Technicon Industrial Systems, Terrytown, NY. Industrial Method Number 158-71W

- (1978) Ammonia in water and seawater. Technicon Industrial Systems, Terrytown, NY. Industrial Method Number 154-78W/B

Tilman D (1984) Plant dominance along an experimental nutrient gradient. Ecology 65: 1445-1453

-(1986) Nitrogen-limited growth in plants from different successional stages. Ecology 67: 555-563

- (1987) Secondary successional and the pattern of plant dominance along experimental nitrogen gradients. Ecological Monographs 57: 189-214

van Veen JA, Ladd JN \& Amatok M (1985) Turnover of carbon and nitrogen through the microbial biomass in a sandy loam and a clay soil incubated with $\left[{ }^{14} \mathrm{C}(\mathrm{U})\right]$ Glucose and $\left[{ }^{15} \mathrm{~N}\right]\left(\mathrm{NH}_{4}\right)_{2} \mathrm{SO}_{4}$ under different moisture regimes. Soil Biology and Biochemistry 17: 747-756

Vitousek PM \& Matson PA (1984) Mechanisms of nitrogen retention in forest ecosystems: a field experiment. Science 225: 51-52

- (1985) Disturbance, nitrogen availability, and nitrogen losses in an intensively managed loblolly pine plantation. Ecology 66: 1360-1376

Vitousek PM, Gosz JR, Greir CC, Melillo JM \& Reiners WA (1982) A comparative analysis of potential nitrification and nitrate mobility in forest ecosystems. Ecological Monographs 52: $155-177$ 
Voroney RP \& Paul EA (1984) Determination of $k_{c}$ and $k_{n}$ in situ for calibration for the chloroform fumigation-incubation method. Soil Biology and Biochemistry 16: 9-14

Zak DR, Groffman PM, Pregitzer KS, Christensen S \& Tiedje JM (1990) The vernal dam: plantmicrobe competition for nitrogen in northern hardwood forests. Ecology 71: 651-656. 